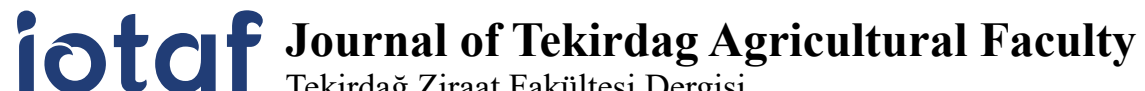 \\ Tekirdağ Ziraat Fakültesi Dergisi
}

Ocak/January 2019, 16(1)

Başvuru/Received: 05/02/18

Kabul/Accepted: 16/04/18

DOI:10.33462/jotaf.516676

http://dergipark.gov.tr/jotaf

http://jotaf.nku.edu.tr/

ARAŞTIRMA MAKALESİ

RESEARCH ARTICLE

\section{Edirne İli Uzunköprü İlçesinde Yetiştirilen Ayçiçeği (Helianthus annuus L.) Bitkisinin Bazı Makro Besin Elementi İçeriklerinin Belirlenmesi*}

Determination of Some Macro Element Contents of Sunflower (Helianthus annuus L.) Plant Grown in Uzunköprü District

\section{Sevinç ADÍLOĞLU' ${ }^{1}$, Ali DERİN²}

\section{$\ddot{O z z}$}

$\mathrm{Bu}$ çalışma Edirne ili Uzunköprü ilçesinde yetiştirilen ayçiçeği (Helianthus annuus L.) bitkisinin bazı makro besin elementi içeriklerinin belirlenmesi amacıyla yapılmıştır. Bunun için Uzunköprü ilçesinin 25 farklı ayçiçeği bitkisi tarlasından yaprak örneği alınarak analiz edilmiştir. Yaprak örneklerine ait analiz sonuçları referans değerler ile karşılaştııılarak incelenen ayçiçeği tarlalarının bazı makro besin elementi durumları ve beslenme sorunları tespit edilmeye çalışılmıştır. Elde edilen bulgulara göre, ayçiçeği tarlalarından alınan örneklerin $\mathrm{N}, \mathrm{P}, \mathrm{K}, \mathrm{Ca}$ ve $\mathrm{Mg}$ içerikleri surasılyla $\% 2,63-\% 3,83 ; \% 0,15-\%, 0,54 ; \% 1,31-\% 5,67 ; \% 2,18-\% 5,41$ ve $\% 0,18-\% 0,80$ arasında bulunmuştur. Bu sonuçlar sınır değerleri ile karşılaştırıldığında; $\mathrm{N} \% 100$ yeterli; fosfor $\% 52$ yeterli, \%48 eksik; K \%80 yeterli, \%20 eksik, \%4 fazla; Ca \%64 yeterli \%36 yüksek ve ise Mg \%64 yeterli \%36 eksik olarak belirlenmiş̧ir.

Anahtar Kelimeler: Makro besin elementi, ayçiçeği, yaprak analizi, Uzunköprü

\begin{abstract}
This study was done to determine the some macro element contents of sunflower (Helianthus annuus L.) plant of Uzunköprü district in Edirne province. For this purpose, leaf samples, which were collected from 25 different agricultural areas of Uzunköprü district and were analyzed. At the end of this research, the leaf samples results were compared with the critical reference values. According to the leaf samples analyzed results, min and max values of $\mathrm{N}, \mathrm{P}, \mathrm{K}, \mathrm{Ca}$ and $\mathrm{Mg}$ macro nutrient elements; 2,63\%- 3,83\%; 0,15\%- 0,54\%; 1,31\%- 5,67\%; 2,18\%$5,41 \%$ and $0,18 \%-0,80 \%$ were obtained, respectively. When these results were compared critical values, $\mathrm{N} 100 \%$ sufficient; P 52\% sufficient, 48\% deficient; K 80\% sufficient, 20\% deficient; Ca $64 \%$ sufficient, $36 \%$ excess and Mg 64\% sufficient, $36 \%$ deficient were obtained.
\end{abstract}

Keywords: Macro nutrient element, sunflower, leaf analysis, Uzunköprü

\footnotetext{
'Sorumlu Yazar/Corresponding Author: Sevinç Adiloğlu, Namık Kemal Üniversitesi Ziraat Fakültesi Toprak Bilimi ve Bitki Besleme Bölümü. Süleymanpaşa, Tekirdağ. E-mail: sadiloglu@nku.edu.tr, (D) OrcID: 0000-0002-0062-0491

${ }_{2}^{2}$ Ali Derin, E-mail: ali-derin@windowslive.com, (D) OrcID: 0000-0002-0516-0711

Atıf/Citation: Adiloğlu, S., Derin, A. Edirne ili Uzunköprü ilçesinde yetiştirilen ayçiçeği (Helianthus annuus l.) bitkisinin bazı makro besin elementi içeriklerinin belirlenmesi. Tekirdağ Ziraat Fakültesi Dergisi, 16(1), 1-10.

*Bu araştırma Yüksek Lisans Tezinden hazırlanmıştır. Bu çalışma, NKÜBAP tarafindan NKUBAP.03.YL.16.045 numaralı proje ile desteklenmiştir.
}

CBu çalışma Tekirdağ Namık Kemal Üniversitesi tarafından Creative Commons Lisansı (https://creativecommons.org/licenses/by-nc/4.0/) kapsamında yayınlanmıștır. Tekirdağ 2019 


\section{Extended Summary}

In recent years, due to the fact that agricultural areas continuously reducing because of many factors such as out of purpose uses, therefore it is necessary that the production in the existing agricultural areas be sustainable in order to get the maximum product from the unit area. The amount of product obtained from the soil depends on many factors such as the use of certified seed, not to use seeds of unknown origin, climate, time, and the cultivation technique. It is important to reveal the nutritional status of the Sunflower (Helianthus annuus L.) which takes an important place in cultivation in the Thrace Region of Turkey. Moreover, it is crucial to carry out the fertilization program for this plant in an appropriate way. For this purpose, the results of the leaf analysis of the plant are considered as a guide to reveal the nutritional deficiencies. Some macro nutrient element contents were determined in leaf samples taken from sunflower plants (Jones ve ark. 1991) grown in 25 different fields in Uzunköprü district of Edirne province. Then, the results of the analysis were compared with the critical values for each element and the nutritional status of plants was determined accordingly. Sunflower plant leaf samples were taken from Hamitli, Kurtbey, Kadıköy, Çakmak, Çöpköy, Ömerbey, Yeniköy, Kavacık, Karapınar and Türkobası villages of Uzunköprü district. Total N, P, K and Ca elemental contents were determined (Kacar and İnal, 2010). Nitrogen contents of plant samples were determined to be between $2.63 \%$ and $3.83 \%$ in this research. Nitrogen contents of sunflower leaf samples taken from 25 points were compared with the limit values specified by Jones et al. (1991) and all were found to be sufficient. Phosphorus contents of plant samples were determined to be between $0.15 \%$ and $0.54 \%$. When the results were compared with those of Jones et al. (1991), $42 \%$ of them were found to be deficient and 52\% of them were found to be sufficient. Potassium contents of plant samples were determined to be between $1.31 \%$ and $5.67 \%$. The potassium contents of $20 \%$ of the plants were deficient while $76 \%$ were sufficient and $4 \%$ were in excess levels when compared with the results of Jones et al. (1991). Calcium contents of plant samples were determined to be between $2.18 \%$ and $5.41 \%$. The calcium contents of $64 \%$ of the plants were sufficient and $36 \%$ of them were in excess levels when compared with the results of Jones et al. (1991). Magnesium contents of plant samples were determined to be between $0.18 \%$ and $0.80 \%$. In the sunflower samples, the desired magnesium limit values suggested by Jones et al. (1991) varies between $0.25 \%$ and $1.00 \%$. The magnesium contents of $64 \%$ of the plants were sufficient and $36 \%$ of them were insufficient when compared with the results of Jones et al. (1991). It was found that the nitrogen contents of the sunflower plants in the subject area subject were at a sufficient level in all samples and these values were among the reference values. When all of the phosphorus-based leaf analyzes was evaluated according to the critical level, $52 \%$ of the plants had sufficient phosphorus contents, while $48 \%$ of them did not have enough phosphorus content. This result suggests that phosphorus fertilizer application was not balanced, so a healthy fertilization program should be done according to the results of the leaf analyses. While $76 \%$ of the potassium analysis results were found to be sufficient, $20 \%$ of the samples were deficient and $4 \%$ had excess potassium. These results show that appropriate fertilizer having nitrogen, phosphorus, and potassium should be applied to the soil of the research areas by taking the soil analysis results of the sunflower plant into account. While calcium levels were sufficient in $64 \%$ of sunflower plant samples, it was found to in excess levels in $36 \%$ of the plants. Magnesium deficiency was found $36 \%$ of the plant samples while $64 \%$ of them were sufficient in terms of magnesium. Fields should be subject to magnesium containing fertilizer application according to the results of the research. This research is very important for sunflower. 
Son yıllarda tarım alanlarının amaç dışı kullanım gibi birçok faktör sebebiyle sürekli olarak daraltılması nedeniyle birim alandan maksimum ürün alınması için, mevcut tarım alanlarındaki üretimin sürdürülebilir olması gereklidir. Topraktan kaldırılan ürün miktarı; toprak, bitki, sertifikalı tohum kullanılması kökeni bilinmeyen tohumların kullanılmaması, iklim, zaman yetiştirme tekniği gibi birçok faktöre bağlıdır. Toprak faktörü içerisinde ise, besin elementi durumunun tespiti ve buna göre yapılması gerekli olan gübreleme programı önemli bir yer tutmaktadır (Sağlam, 2012; Bellitürk 2011).

Toprağın verimliliğinde en önemli husus, topraktaki bitki besin elementlerinin bitkilere yarayışlı ve elverişli miktarının en hassas ve doğru bir şekilde belirlenmesidir. Verimli toprak irdelendiğinde bitki besin elementleri bitkilerde yeterli miktarlarda ve dengeli oranlarda bitki kök bölgesinde bulunması gerekir. Ayrıca bitki gelişimi açısından toprakta toksik ağır metallerin veya hastalık gibi olumsuz koşulların oluşmaması gerekmektedir (Karaman ve ark., 2012).

Tarım alanlarının amaç dışı kullanımı, kirlilik gibi birçok nedenlerle azalması insanoğlunun beslenme ihtiyacının karşılanmasını gittikçe güçleştirmiştir. Bu ihtiyacı gidermek için birim alandan en yüksek verimi almanın önemi daha da artmaktadır. Yüksek verim almak içinde bilinçli ve etkin tarım sistemlerinin kullanılması gerekmektedir. Doğru ve etkin gübreleme ve sulama programları bitkisel üretiminde önceliğini artmıştır (Adiloğlu ve Eraslan, 2012).

Ülkemizde ayçiçeği (Helianthus annuus L.) yetiştiriciliğinde ilk sırayı alan Trakya Bölgesi için önemli bir kültür bitkisi olan ayçiçeği bitkisinin beslenme durumunun net olarak ortaya konulması ve gübreleme programının doğru bir biçimde yapılması büyük önem taşımaktadır. Bunun için de bitkinin yaprak analizi sonuçları beslenme noksanlıklarının ortaya konulmasında bir rehber olarak kabul edilmektedir.

Türkiye'de ayçiçeği ekilen alan son yıllarda yaklaşık olarak 5 milyon dekar ile 6 milyon dekar arasında değişmektedir. 2013-2016 yılları arasında ayçiçeği üretimi ise 1.380 .000 ton ile 1.500 .000 ton arasında değişmektedir. Verim açısından irdelendiğinde son dört yılda ortalama verimin $265-244 \mathrm{~kg} / \mathrm{da}$ arasında değiştiği görülmektedir. Edirne ili olarak ayçiçeği tarımı değerlendirildiğinde son dört yıldaki veriler ülke geneli değerlerinin altında olmakla birlikte Uzunköprü ilçesinde Edirne ili değerlerinin üzerinde olduğu bilinmektedir. Aynı zamanda Uzunköprü ilçesi ayçiçeği tarımı açısından Edirne ilinin diğer ilçeleriyle karşılaştırıldığında ilk sırayı almaktadır (TÜİK, 2017).

Ayçiçeği bitkisi, tohumunun içeriğinde önemli miktarlarda protein, karbonhidrat ve yă̆ bulundurması nedeniyle insan beslenmesinde olduğu kadar, hayvansal üretimde hayvan yemi olarak da kullanılmaktadır. Ayrıca ayçiçeği bitkisi son zamanlarda bir süs bitkisi olarak park ve bahçelerde de kullanılmaktadır. Ayçiçeği bitkisi sağlıklı beslenme bakımından değerlendirildiğinde de önemli bir kültür bitkisidir. Ayçiçeği bitkisinin özellikle potasyum ve E vitamini içeriği yüksektir. Ayçiçeği çekirdeği aynı zamanda önemli bir linoleik asit kaynağıdır (Büyükfiliz, 2016).

Güneri ve ark. (2016) tarafından yapılan bir araştırmada artan miktarlarda fosfor ve potasyumlu gübre uygulamalarının kamkat (Fortunella margarita L.) bitkisinin fidan gelişimi, meyve özellikleri, verim ve beslenme düzeylerine etkisi incelenmiştir. Saksı denemesi yapılarak bitkilere üç farklı doz fosfor (10, $40 \mathrm{ve} 80 \mathrm{mg} / \mathrm{kg})$ $\mathrm{NH}_{4} \mathrm{H}_{2} \mathrm{PO}_{4}$ formunda ve üç farklı doz potasyum $(150,300$ ve $450 \mathrm{mg} / \mathrm{kg}) \mathrm{K}_{2} \mathrm{SO}_{4}$ şeklinde birbiri ile kombine edilerek modifiye edilmiş Hoagland çözeltisine ilave edilerek topraktan uygulanmıştır. Denemenin sonunda fosforlu ve potasyumlu gübrelerin 2. dozları (40 mg/kg fosfor ve $300 \mathrm{mg} / \mathrm{kg}$ potasyum); bitkinin kök uzunluğu, meyve ağırlığı, meyve sayısı ve verimini en yüksek düzeylere çıkarmıştır. Fosfor uygulamaları bitki yapraklarının $\mathrm{N}, \mathrm{P}, \mathrm{Fe}$ ve Mn kapsamları artmış; potasyum uygulamaları ise bitki yapraklarının sadece K miktarlarında artışa neden olmuştur. Eryilmaz Açıkgöz ve ark. 2017 tarafından roka bitkisi ile ilgili yapılan araştırmada da benzer veriler ortaya konulmuştur.

Ayçiçeği potasyum ihtiyacı açısından mısır bitkisi ile karşılaştırıldığında; ayçiçeğinin potasyumu daha fazla kaldırdığı anlaşılmaktadır. Yapılan birçok çalışma bitkilerde protein sentezinde potasyumun önemli olduğunu göstermiştir. Potasyum ayçiçeğinde yağ sentezini kolaylaştırmakta ve yağ oranını önemli ölçüde etkilemektedir. Farklı pH' lar da ekstrakte edilebilir potasyumun değişimi yağ oranını etkilemektedir (Adiloğlu ve ark., 2010).

Doğu Karadeniz Bölgesi findık bahçelerinin beslenme durumlarını toprak ve bitki analizleri ile incelendiği bir araştırmada, 30 farklı findık bahçesinden toprak ve yaprak örnekleri alınmıştır. Alınan bu örnekler analiz edilmiş ve araştırma bölgesindeki bazı makro bitki besin elementlerinin eksikliklerinin önemli boyutlarda olduğu görülmüştür. Söz konusu bu bitki besin elementi eksiklikleri \%73,4 oranında $\mathrm{Ca}, \% 50,0$ oranında $\mathrm{Mg}, \% 26,7$ oranında P, \%20,0 oranında N ve \%6,7 oranında K şeklinde bulunmuştur (Adiloğlu ve Adiloğlu, 2005). 
Bu araştırmada Edirne li Uzunköprü İlçesi'nde yetiştirilen ayçiçeği (Helianthus annuus L.) bitkisinin bazı makro bitki besin elementleri içerikleri alınan yaprak örneklerinde yapılan $\mathrm{N}, \mathrm{P}, \mathrm{K}, \mathrm{Ca}$ ve $\mathrm{Mg}$ analizleriyle ortaya konularak beslenme durumunun yeterli olup olmadığı değerlendirilmiştir.

\section{Materyal ve Yöntem}

Edirne ili Uzunköprü ilçesi'nde 25 farklı tarlada yetiştiriciliği yapılan ayçiçeği bitkisinden alınan yaprak örneklerinde (Jones ve ark. 1991) bazı makro bitki besin elementi (N, P, K, Ca ve Mg) analizleri yapılmıştır. Daha sonra elde edilen analiz sonuçları her bir element için kritik değerler ile karşılaştırılmış ve bitkinin her bir element ile beslenme durumu ortaya konulmuştur.

Ayçiçeği bitki örnekleri Uzunköprü ilçesinin Hamitli, Kurtbey, Kadıköy, Çakmak, Çöpköy, Ömerbey, Yeniköy, Kavacık, Karapınar, Türkobası köylerinden alınmıştır. Alınan bitki örneklerinde toplam N, P, K, Ca ve Mg bitki besin elementi içerikleri belirlenmiştir (Kacar ve İnal 2010).

Bitkilerin Bazı Makro Besin Elementi İçerikleri

\section{Bulgular ve Tartışma}

Araştırma noktalarından alınan ayçiçeği bitkisinin N, P, K, Ca ve Mg içerikleri Tablo 1'de verilmiştir.

Tablo 1. Ayçiçeği bitkisi yaprak örneklerinin bazı makro besin elementi içerikleri, \%

Table 1. Some macro nutrient element contents of sunflower plant samples, \%

\begin{tabular}{|c|c|c|c|c|c|}
\hline $\begin{array}{c}\text { Örnek } \\
\text { No }\end{array}$ & $\begin{array}{l}\text { Azot } \\
(\mathbf{N})\end{array}$ & $\begin{array}{c}\text { Fosfor } \\
\text { (P) }\end{array}$ & $\begin{array}{l}\text { Potasyum } \\
\text { (K) }\end{array}$ & $\begin{array}{l}\text { Kalsiyum } \\
\text { (Ca) }\end{array}$ & $\begin{array}{c}\text { Magnezyum } \\
\text { (Mg) }\end{array}$ \\
\hline 1 & 2,63 & 0,26 & 2,21 & 2,83 & 0,26 \\
\hline 2 & 3,54 & 0,26 & 2,43 & 2,44 & 0,22 \\
\hline 3 & 2,93 & 0,27 & 1,89 & 2,78 & 0,36 \\
\hline 4 & 3,02 & 0,18 & 2,11 & 2,35 & 0,24 \\
\hline 5 & 3,75 & 0,26 & 2,65 & 2,61 & 0,24 \\
\hline 6 & 3,77 & 0,35 & 2,67 & 2,84 & 0,35 \\
\hline 7 & 3,33 & 0,24 & 2,98 & 2,38 & 0,25 \\
\hline 8 & 3,15 & 0,29 & 3,38 & 3,40 & 0,18 \\
\hline 9 & 3,13 & 0,15 & 2,34 & 2,92 & 0,27 \\
\hline 10 & 2,74 & 0,22 & 2,25 & 2,86 & 0,24 \\
\hline 11 & 3,58 & 0,31 & 2,15 & 3,08 & 0,29 \\
\hline 12 & 3,16 & 0,25 & 2,54 & 3,20 & 0,30 \\
\hline 13 & 3,83 & 0,28 & 3,17 & 2,88 & 0,26 \\
\hline 14 & 3,16 & 0,24 & 2,08 & 2,66 & 0,37 \\
\hline 15 & 3,76 & 0,54 & 5,67 & 5,41 & 0,64 \\
\hline 16 & 3,03 & 0,33 & 2,46 & 3,39 & 0,20 \\
\hline 17 & 2,88 & 0,28 & 2,31 & 3,44 & 0,41 \\
\hline 18 & 2,98 & 0,18 & 1,98 & 2,19 & 0,27 \\
\hline 19 & 3,48 & 0,23 & 2,70 & 2,18 & 0,18 \\
\hline 20 & 3,09 & 0,22 & 1,31 & 2,86 & 0,48 \\
\hline 21 & 3,03 & 0,22 & 2,28 & 2,50 & 0,34 \\
\hline 22 & 2,98 & 0,23 & 2,73 & 2,94 & 0,18 \\
\hline 23 & 3,16 & 0,25 & 1,90 & 3,02 & 0,43 \\
\hline 24 & 2,88 & 0,26 & 2,18 & 3,06 & 0,44 \\
\hline 25 & 2,97 & 0,24 & 1,49 & 3,28 & 0,80 \\
\hline Min. & 2,63 & 0,15 & 1,31 & 2,18 & 0,18 \\
\hline Max. & 3,83 & 0,54 & 5,67 & 5,41 & 0,80 \\
\hline
\end{tabular}

\section{Bitkilerin Azot İçerikleri}

Bu araştırmada alınan yaprak örneklerinin azot içeriklerinin \%2,63 ile \%3,83 arasında değiştiği görülmektedir (Şekil 1.) 


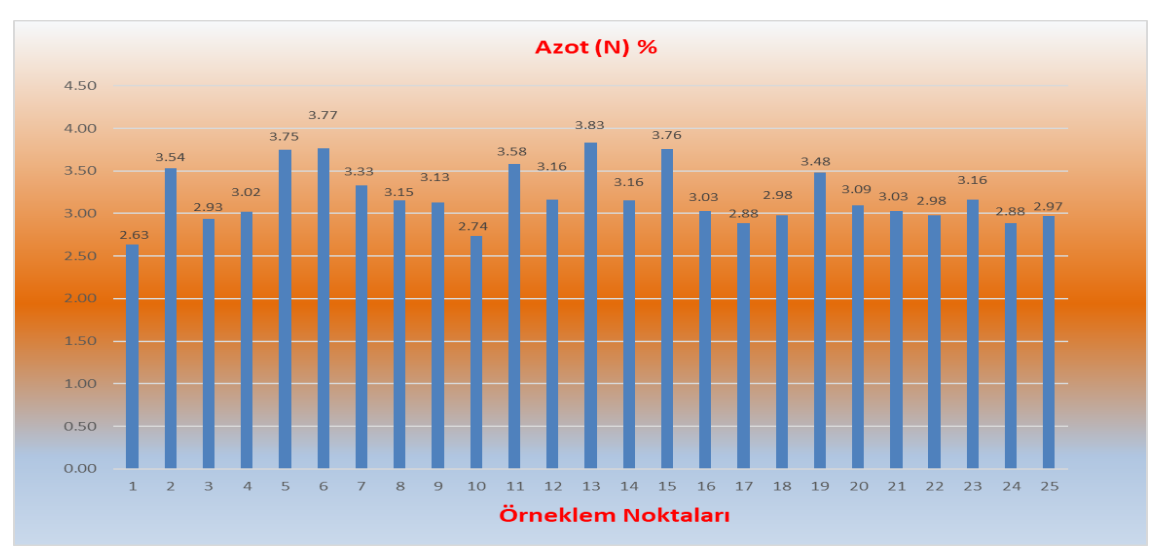

Şekil 1. Bitki örneklerinin $\mathbf{N}$ içerikleri

Figure 1. Nitrogen contents of plant samples

Ayçiçeği yaprak örneklerinin azot içerikleri Jones ve ark. (1991) tarafından belirtilen sınır değerleri ile karşılaştırıldığında 25 noktadan alınan bitki örneklerinin \%100'ünde azot miktarlarının yeterli düzeyde olduğu görülmüştür (Şekil 2.). Eryilmaz Açıkgöz (2011) karalahana ile ilgili yapılmış araştırmada farklı hasat olgunluklarında bitkinin makro ve mikro bitki besin elementlerinin içeriğindeki değişim incelenmiştir. Bitki farklı olmakla birlikte azot açısından en yüksek değeri bu bitki için tam hasat olgunluk döneminde yapılan hasatdaki örneklemede olduğu görülmüştür. Ayçiçeği bitkisinde bütün örneklerde yeterli çıkmasının bir nedenin de bu durum olduğu düşünülmektedir.

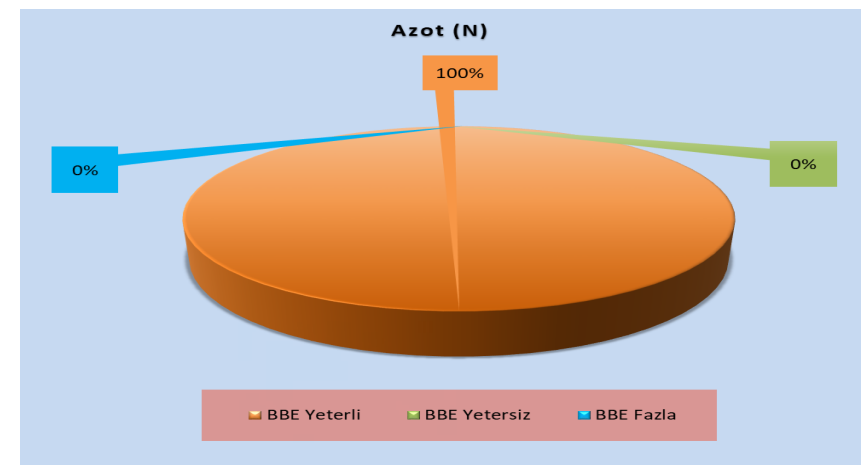

Şekil 2. Azot elementinin sınır değerlerine göre değerlendirilmesi

Figure 2. Evaluation of $\mathbf{N}$ contents of plants according to critical values

$\mathrm{Bu}$ çalışmanın sonuçları ile benzerlik gösteren bir araştırma Doğu Karadeniz Bölgesi çay tarımının yapıldığı bahçelerde belirlenmiştir (Adiloğlu ve Adiloğlu, 2006). Araştırma konusu çay bahçelerinin tamamında bitkilerin $\mathrm{N}$ içerikleri yeterli ve yüksek düzeylerde olduğu ortaya konulmuştur.

Tekirdağ ili Muratlı ilçesinde yapınla bir araştırmada ise buğday bitkisi yaprak örneklerinde N eksikliği sadece \% 10 düzeyinde olduğu belirlenmiştir (Çaktü, 2016).

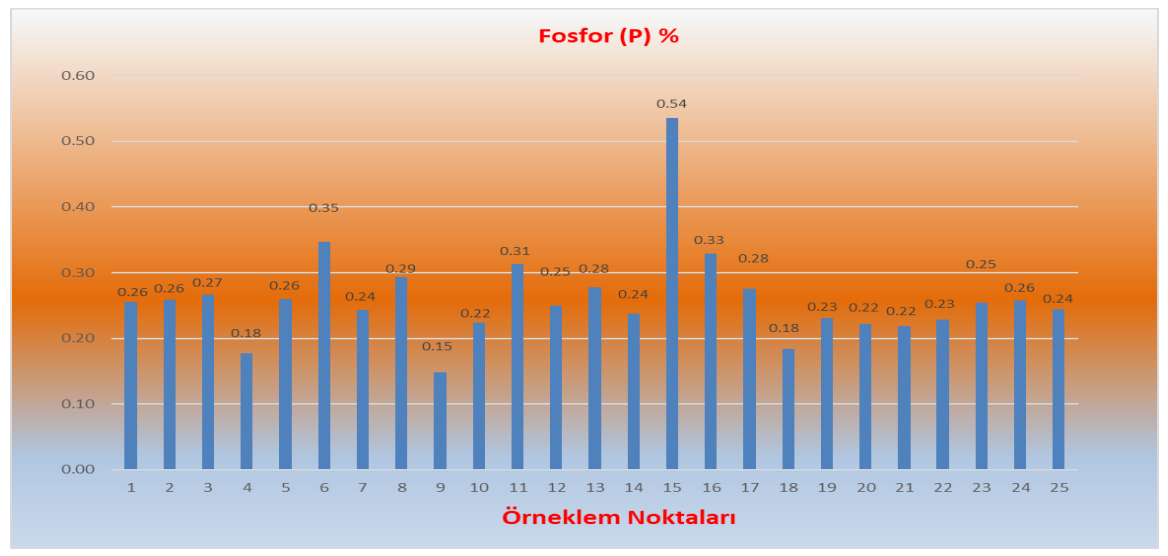

Şekil 3. Bitki örneklerinin P içerikleri

Figure 3. Phosphorus contents of plant samples. 


\section{Bitkilerin Fosfor İçerikleri}

$\mathrm{Bu}$ araştırmada alınan yaprak örneklerinin fosfor içeriklerinin $\% 0,15$ ile $\% 0,54$ arasında değiştiği görülmektedir (Şekil 3.) Ayçiçeği bitkisinde fosforun Jones ve ark. (1991)'e göre \%0,25 - \%0,60 arasında yeterlilik düzeyi bulunmaktadır. Alınan yaprak örneklerinin fosfor içeriklerinin Jones ve ark. (1991) tarafından oluşturulan sınır değerler ile karşılaştırıldığında örneklerin \%42' sinde fosfor eksikliğinin olduğu görülmüştür. Bitki örneklerinin $\% 52$ ' sinde ise fosfor düzeyleri yeterli olduğu belirlenmiştir (Şekil 4.).

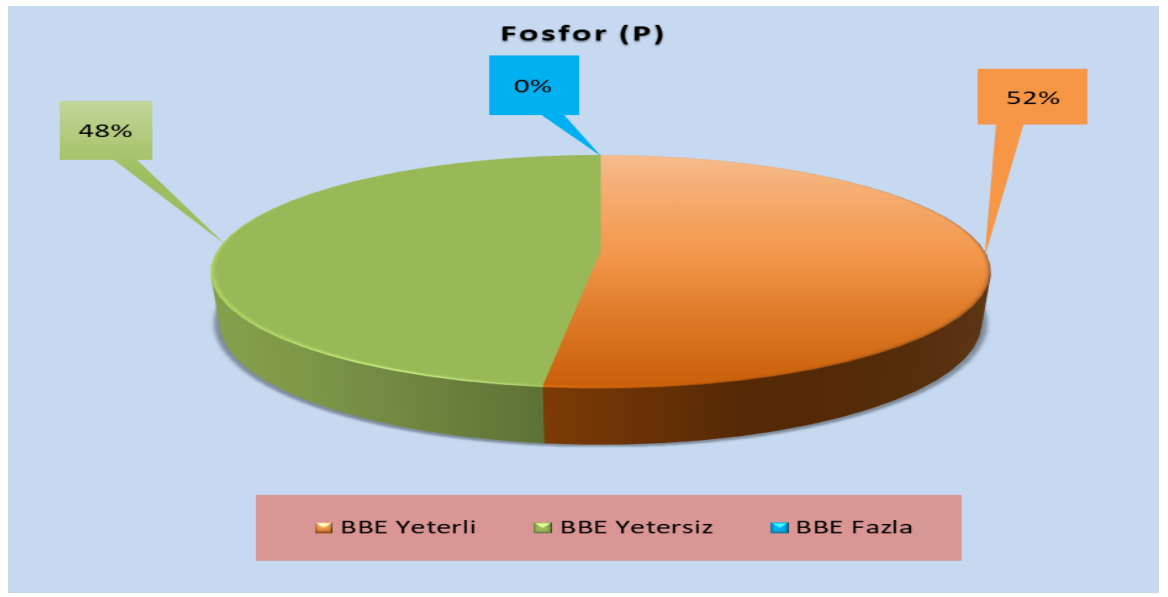

Şekil 4. Fosfor elementinin sınır değerlerine göre değerlendirilmesi

Figure 4. Evaluation of $P$ contents of plants according to critical values

Ceviz bahçelerinin beslenme durumlarının bitki analizleriyle değerlendirildiği bir araștırmada, incelenen bahçelerde bitkilerin P eksikliklerinin \%4,39 oranında olduğu, ceviz bahçelerinin \%89,13' unda ise bitkilerin fosfor içeriklerinin ise yeterli olduğu belirlenmiştir (Solmaz ve Adiloğlu, 2017).

\section{Bitkilerin Potasyum İçerikleri}

$\mathrm{Bu}$ araştırmada alınan yaprak örneklerinin potasyum içeriklerinin \%1,31 ile $\% 5,67$ arasında değiştiği görülmektedir (Şekil 5).

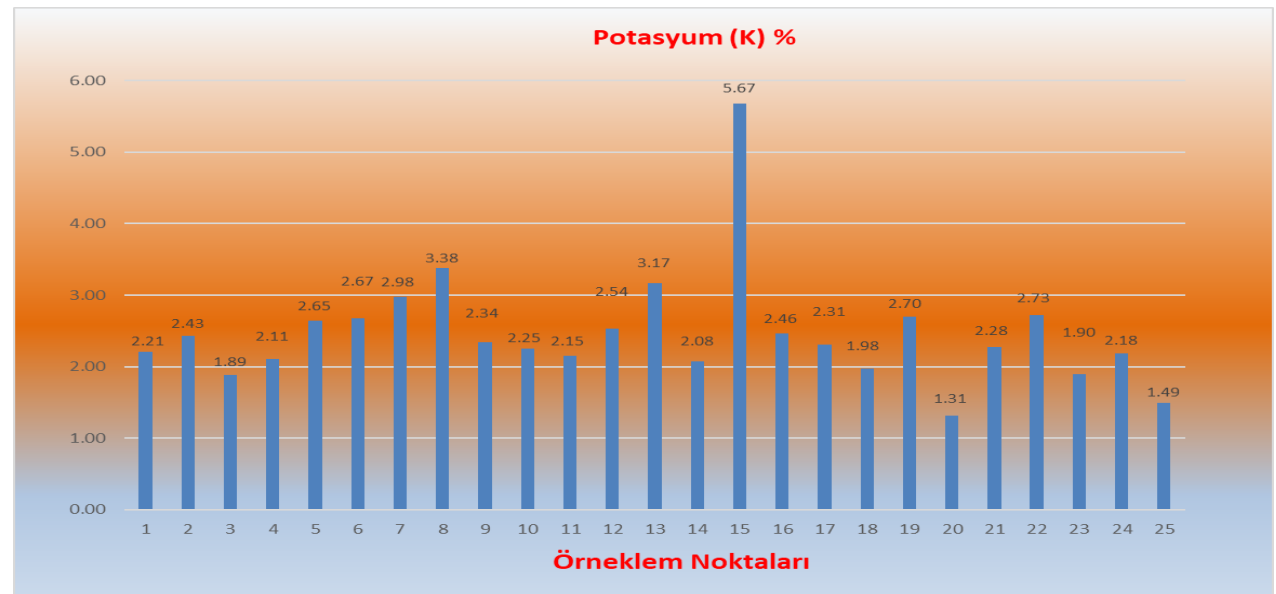

Şekil 5. Bitki örneklerinin K içerikleri

Figure 5. Potassium contents of plant samples

Söz konusu bu değerler Jones ve ark. (1991)' e göre değerlendirildiğinde bitkilerin potasyum içeriklerinin \%76' sı yeterli, \%4'ü fazla \%20'si ise yetersizdir (Şekil 6). Bu çalışmanın sonuçlarına benzer bir şekilde karayemiş (Prunus laurocerasus L.) bitkisi ile yapılan bir çalışmada bitki yaprak örneklerinin potasyum içeriklerinin \%55 'inin yeterli ve \%45'inin ise fazla düzeylerde olduğu belirlenmiş̧ir (Adiloğlu ve ark., 2013). 


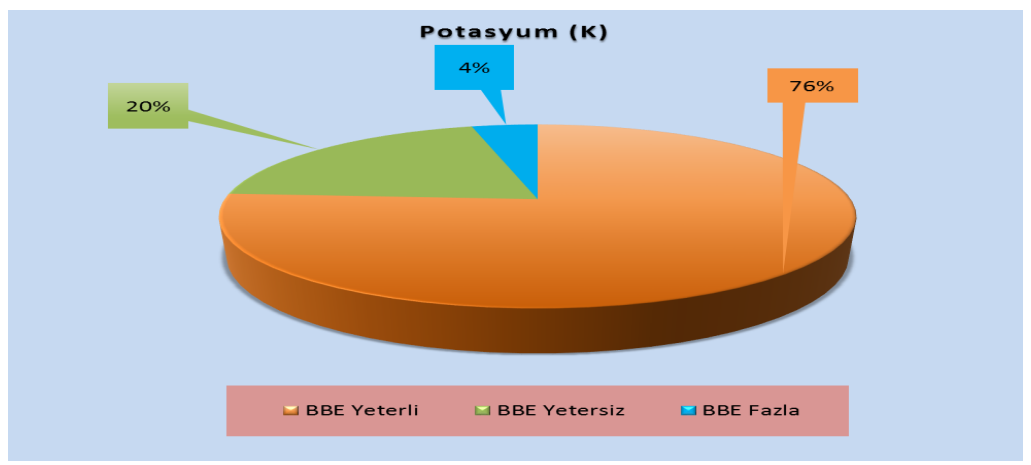

Şekil 6. Potasyum elementinin sınır değerlerine göre değerlendirilmesi

Figure 6. Evaluation of $K$ contents of plants according to critical values

\section{Bitkilerin Kalsiyum İçerikleri}

$\mathrm{Bu}$ araştırmada kullanılan ayçiçeği yaprak örneklerinin kalsiyum içerikleri \%2,18 ile \%5,41 arasında değişkenlik göstermiştir (Şekil 7).

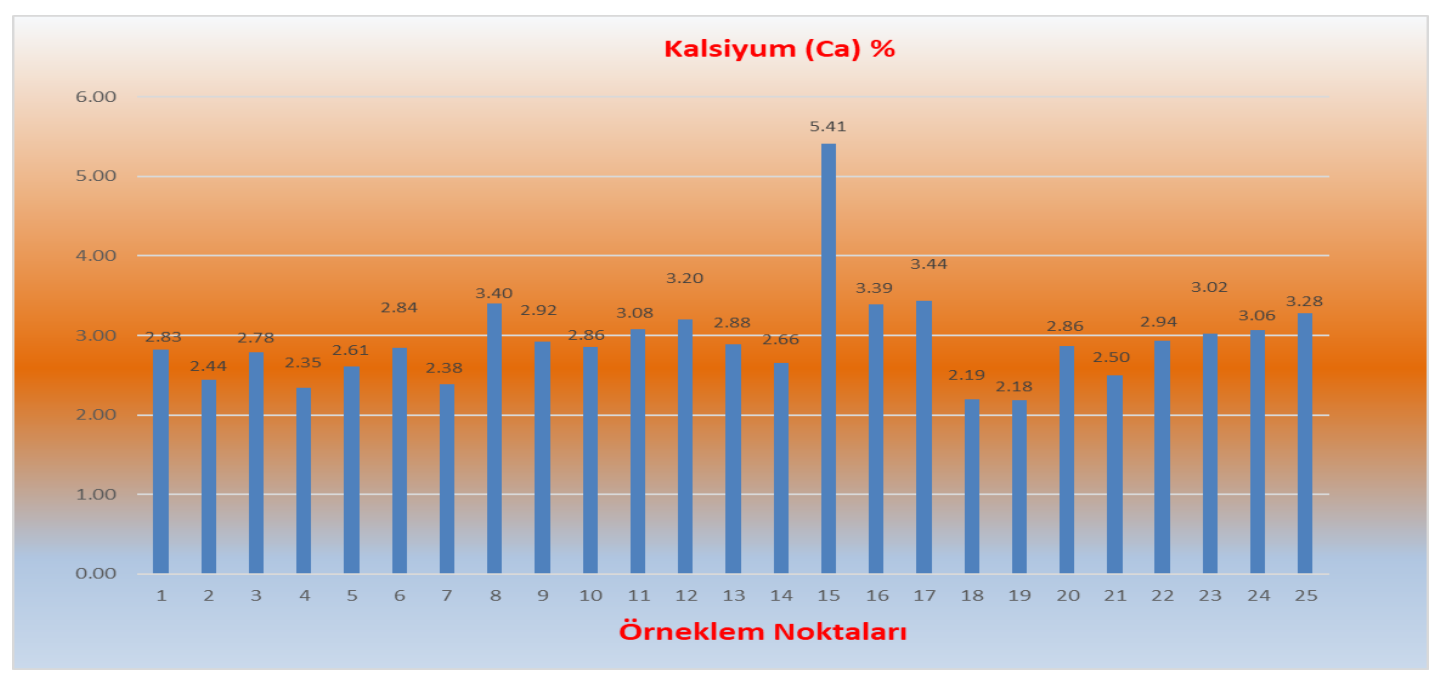

Şekil 7. Bitki örneklerinin Ca içerikleri

Figure 7. Calcium contents of plant samples

Ayçiçeği örneklerinin kalsiyum içerikleri Jones ve ark. (1991) tarafından belirlenen refereans verileriyle karşılaştırıldığında örneklerin \%36'sının Ca içerikleri fazla ve \%64'ünün ise yeterli olduğu tesbit edilmiştir (Şekil 8.).

Ceviz bahçelerinin kalsiyum içeriklerinin incelendiği bir araştırmada (Solmaz ve Adiloğlu, 2017), inceleme konusu ceviz bahçelerinin $\% 84,78$ 'inin kalsiyum içeriklerinin yeterli ve \%13,04'ünün ise fazla düzeylerde kalsiyum içeriğine sahip olduğu belirlenmiştir.

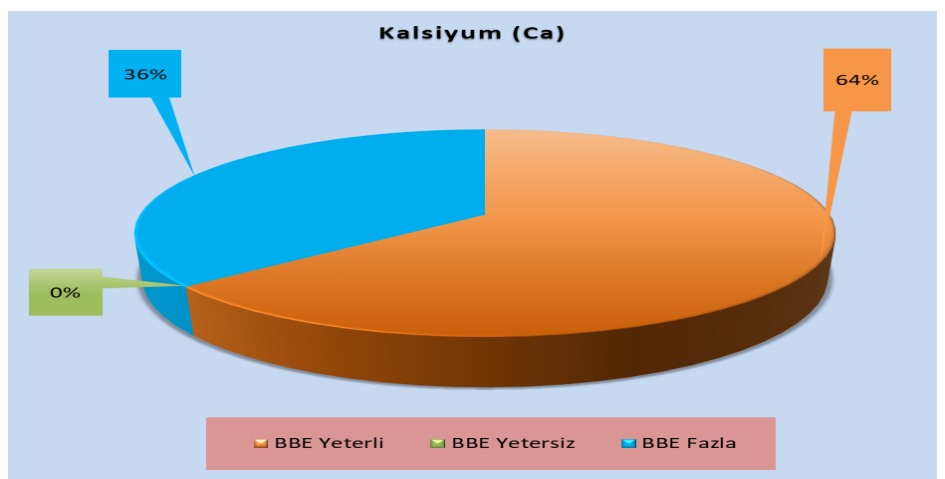

Şekil 8. Kalsiyum elementinin sınır değerlerine göre değerlendirilmesi

Figure 8. Evaluation of $\mathrm{Ca}$ contents of plants according to critical values 


\section{Bitkilerin Magnezyum İçerikleri}

9.)

Ayçiçeği yaprak örneklerinin magnezyum içeriklerinin $\% 0,18$ ile $\% 0,80$ arasında değiștiği belirlenmiştir (Şekil

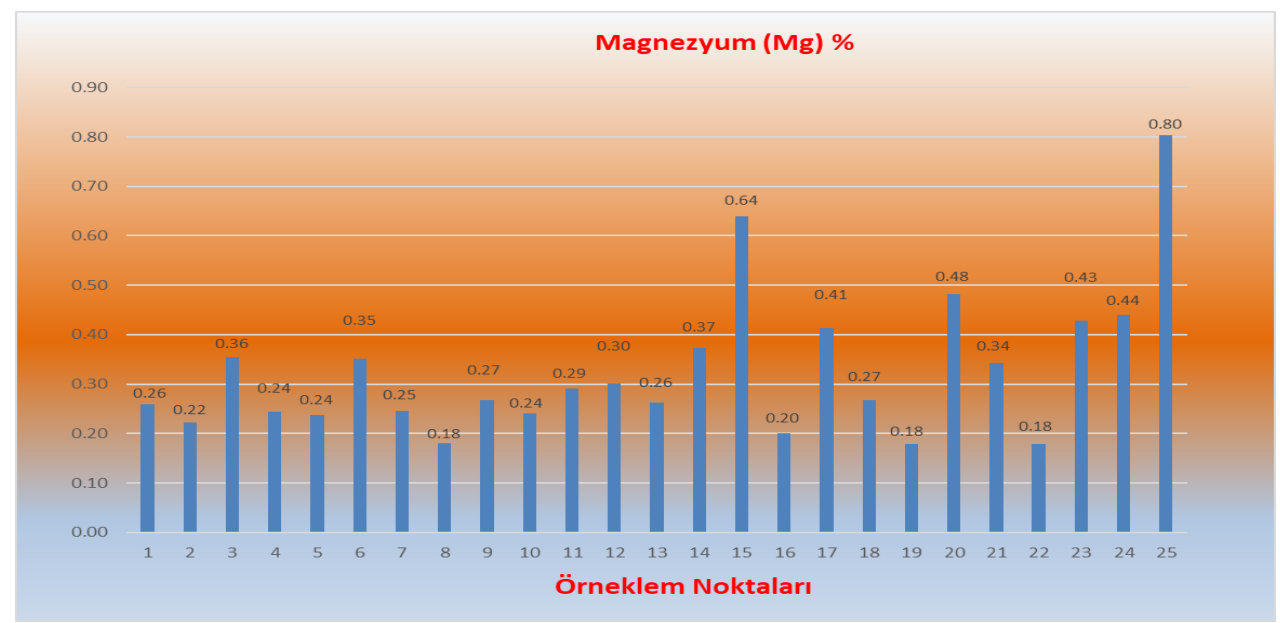

Şekil 9. Bitki örneklerinin Mg içerikleri

Figure 9. Magnesium contents of plant samples

Ayçççeği örneklerinde istenen magnezyumun Jones ve ark. (1991)'e göre yeterlilik sınırı \% 0,25 - \% 1,00 arasında değişmektedir. Alınan yaprak örneklerinin magnezyum içeriklerinin Jones ve ark. (1991) tarafindan belirlenen refereans değerleri ile kıyaslandığında örneklerin \%64'ü yeterli \%36'sı yetersiz olduğu tespit edilmiștir (Şekil 10).

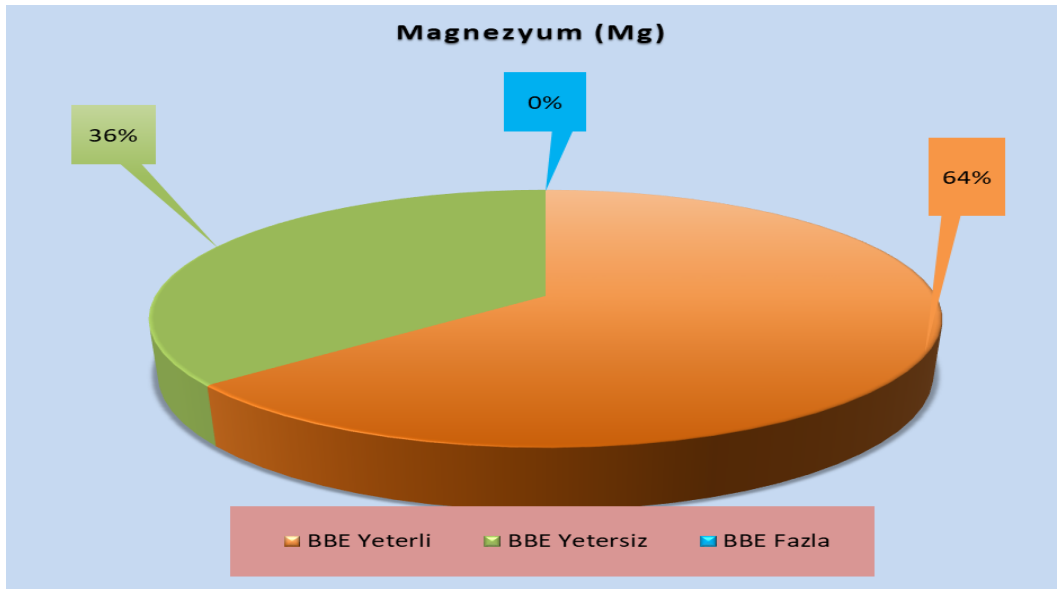

Şekil 10. Magnezyum elementinin sınır değerlerine göre değerlendirilmesi

Figure 10. Evaluation of $\mathrm{Mg}$ contents of plants according to critical values

\section{Sonuç ve Öneriler}

Edirne ili Uzunköprü ilçesinde belirlenen köylerde yer alan Ayçiçeği tarlalarının mutlak gerekli bazı makro bitki besin elementi içeriklerinin belirlenmesi amacı ile Uzunköprü ilçesinin 10 farklı köyünde bulunan 25 farklı ayçiçeği tarlasından, bitkilerden alınan yaprak örneklerinin analizleri sonucunda, gerekli analizler yapılarak sonuçları değerlendirilmiştir.

Elde edilen sonuçlara göre araştırmaya konu olan bölgedeki ayçiçeği bitkisinin azot içeriklerinin \%100'ünün yeterli seviyede olduğu ve bu değerlerin referans değerler arasında olduğu görülmüştür. Fosfor açından yaprak analizlerinin tamamı kritik seviyeye göre değerlendirildiğinde, bitkilerin $\% 52$ 'sinin fosfor içerikleri yeterli miktarda iken \%48'inin fosfor içeriklerinin yetersiz olduğu belirlenmiştir. Bu sonuç bize fosforlu gübre uygulamasının dengeli olarak yapılmadığı, toprak ve yaprak analizleri dikkate alınarak sağlıklı bir gübreleme programının yapılması gerekliliğini ortaya koymaktadır. Diğer bir element potasyum analiz sonuçlarının \%76'sının yeterli seviyede olduğu belirlenirken, örneklerin \%20'sinde eksiklik, \%4'ünde ise potasyum fazlalığı olduğu ortaya konulmuştur. Bu sonuçlar gösteriyor ki ayçiçeği bitkisinin toprak analiz sonuçları da dikkate alınarak azot, fosfor, potasyumlu gübre uygulanmalıdır. 
Ayçiçeği bitki örneklerinin \%64'ünde kalsiyum yeterli seviyede iken, \%36'sında ise fazla olduğu belirlenmiştir. Magnezyum açısından bitki örneklerinin değerlendirildiğinde \%64'ü yeterli \%36'sında ise magnezyum yetersizliği olduğu belirlenmiştir. Toprak ve bitki analizleri sonucunda eksikliği olan tarlalarda bu eksikliğin giderilmesi için yapraktan magnezyum içerikli gübreler ile gübreleme yapılması gerekmektedir.

Bu araştırmanın sonuçlarına göre, en yüksek besin elementi eksikliği \%48 ile fosfor eksikliği, \%36 magnezyum eksikliği ve \%20 potasyum eksikliği gözlenmiş olup, gübreleme programları bu besin elementlerinin eksiklikleri göz önünde bulundurularak oluşturulmalıdır.

Bu araştırma sonuçlarına göre, bölgede özellikle fosfor, magnezyum ve potasyum gübrelemesine özel bir önem verilmelidir. Diğer taraftan da özellikle gübre kaynaklı kirlilik sonucunda oluşan toksisitenin önüne geçmek ve insan sağlığına etki edecek şartların ortadan kaldırılması için de gübreleme uygulamalarında bilinçli olarak hareket edilmelidir.

\section{Teşekkür}

Bu araştırma Yüksek Lisans Tezinden hazırlanmıştır. Bu çalışma, NKÜBAP tarafından NKUBAP.03.YL.16.045 numaralı proje ile desteklenmiştir. 


\section{Kaynakça/References}

Adiloğlu, A. \& Adiloğlu, S. (2005). An Investigation on nutritional problems of hazelnut (Corylus avellana L.) grown in acid soils. Communications in Soil Science and Plant Analysis, 36(15-16), 2219-2226.

Adiloğlu, A. \& Adiloğlu, S. (2006). An Investigation on nutritional status of tea (Camellia sinensis L.) grown in Eastern Black Sea Region of Turkey. Pakistan Journal of Biological Sciences, 9(3), 365-370

Adiloğlu, A., Karaman, M.R., Adiloğlu, S. \& Karakaş, Ö. (2013). Elementel composition of cherry laurel (Prunus laurocerasus L.) grown natural conditions in Eastern Black Sea Region of Turkey. Soil Water Journal, 2(1), 753-760.

Adiloğlu, A., ve Eraslan, F. (2012). Bitki Besleme. (Ed. M.R. Karaman). Bölüm 4. Gübreler ve Gübreleme Tekniği, s:347-474, Gübretaş Rehber Kitaplar Dizisi: 2, Dumat Ofset Matbaacılık Ltd. Şti., Ankara.

Adiloğlu, S., Sümer, A., Gönülsüz, E. \& Adiloğlu A. (2010). Determination of suitable chemical extraction methods for exchangeable potassium content of having different $\mathrm{pH}$ value soils in Tekirdağ. Soil Management and Potash Fertilizer Uses in West Asia and North Africa Region, International Symposium of Potash Institute Held. Antalya, November, 22-25.

Bellitürk K. (2011). Edirne İli Uzunköprü ilçesi tarım topraklarının beslenme durumlarının belirlenmesi. Tekirdă̆ Ziraat Fakültesi Dergisi, 8(3): 8-15.

Büyükfiliz, F. (2016). Vermikompost gübrelemesinin ayçiçeği bitkisinin verim ve bazı kalite parametreleri üzerine etkisi. Namık Kemal Üniversitesi Fen Bilimleri Enstitüsü, Toprak Bilimi ve Bitki Besleme Anabilim Dalı, Yüksek Lisans Tezi Tekirdağ.

Çaktü, E. (2016). Tekirdă̆ İli Muratlı ilçesinde yetiştirilen buğday (Triticum aestivum L.) bitkisinin beslenme durumunun bitki analizleriyle belirlenmesi. Namık Kemal Üniversitesi Fen Bilimleri Enstitüsü Toprak Bilimi ve Bitki Besleme Anabilim Dalı, Yüksek Lisans Tezi, 34 $\mathrm{s}$, Tekirdağ.

Açıkgöz F.E. (2011). Mineral, vitamin C and crude protein contents in kale (Brassica oleraceae var. acephala) at different harvesting stages. African Journal of Biotechnology, 10:17170-17174.

Açıkgöz, F.E., Adiloğlu, S., Solmaz, Y. \& Adiloğlu, A. (2017). The Influence of potassium fertilizer practices on some macro and micro nutrient element ingredient of rocket (Eruca vesicaria subsp. sativa) plant. Oxidation Communications, 40(3): 1209-1217.

Güneri, M., Akat, H., Yağmur, B. \& Yokaş, İ. (2016). Effect of phosphorus and potassium applications on growth of kumquat (Fortunella margarita L.) swing plant. Journal of Agricultural Faculty of Gaziosmanpaşa University, 33(1): 64-74.

Jones, J.B., Wolf B. \& Mills, H.A. (1991). Plant Analysis Handbook. Micro-Macro Publishing, Inc., USA, $213 p$.

Kacar, B. \& İnal, A. (2010). Bitki Analizleri. Nobel Yayınları No:1241.

Karaman, M.R., Brohi, A.R., Müftüoğlu, N.M., Öztaș, T. \& Zengin, M. (2012). Sürdürülebilir Toprak Verimliliği. Koyulhisar Ziraat Odası Kültür Yayınları No:1 Güncellenmiş 3. Baskı. ISBN 978-605-86684-0-9.

Sağlam, M.T. (2012). Gübreler ve Gübreleme. Namık Kemal Üniversitesi Yayınları. Yayın No: 14, Ders Kitabı No: 6, Tekirdağ.

Solmaz, Y. \& Adiloğlu, A. (2017). Determination of nutritional status of walnut orchards by leaf analysis in Tekirdağ Region. Tekirda $\breve{g}$ Ziraat Fakültesi Dergisi, 14(1): 88-92.

TUİK, 2017. Tarım İstatistikleri. Türkiye İstatistik Kurumu, Ankara. 